\title{
A SIDE EFFECT OF DWORKIN'S THEORY: THE IMPROVEMENT OF POSITIVISM*
}

\author{
UN EFECTO SECUNDARIO DE LA TEORIA DE DWORKIN: \\ MEJORÍAS EN EL POSITIVISMO JURIDICO
}

David GARCÍA SARUBBI**

Resumen:

Sin lugar a dudas se puede considerar a Dworkin como el fundador de una tradición jurídica contraria a la corriente del positivismo jurídico. Con apoyo de premisas novedosas, diferentes a las del iusnaturalismo anterior, su propósito es articular una filosofia jurídica que haga patente el vínculo conceptual entre el derecho y el razonamiento moral. El propósito de este artículo es conducir la teoria dworkiniana hacia un destino difícilmente imaginado por el propio Dworkin: la renovación del positivismo jurídico y de su principal objetivo de separar el derecho y la moral. La estrategia consiste en realizar una operación quirúrgica, esto es, implantar conceptos dworkinianos en el positivismo jurídico, e intentar alcanzar cierta compatibilidad entre ambas teorias. Al interior del positivismo jurídico hay una amplio desacuerdo sobre esta empresa; y hay cuando menos un sector no interesado en realizar tal acercamiento. Sin embargo, este artículo se inscribe en el tipo de positivismo jurídico que cree poder beneficiarse de esta operación, un positivismo no casual, el cual se vincula con un ideal de "estado de derecho". Así, el objetivo de este artículo es poner a prueba el éxito de este complicado transplante.

* Artículo recibido el 10 de abril del 2012 y aceptado para su publicación el 23 de mayo de 2013.

** Licenciado en derecho por el Instituto Tecnológico Autónomo de México, maestro en Derecho por la Universidad de Nueva York, especialista en derecho constitucional por la UNAM. Secretario de Estudio y Cuenta en la Suprema Corte de Justicia de la Nación, dgarcias@mail.scjn.gob.mx 
Esta revista forma parte del acervo de la Biblioteca Jurídica Virtual del Instituto de Investigaciones Jurídicas de la UNAM

\author{
DAVID GARCÍA SARUBBI
}

\title{
Palabras clave:
}

Positivismo jurídico, razonamiento moral, estado de derecho, metodologia jurídica, Dworkin, Ronald M.

\begin{abstract}
:
It is not controversial to claim that Dworkin has founded a legal tradition that challenges mainstream positivism. Based upon renewed premises, his aim is to articulate a legal philosophy different from prior Natural Law Theory that shows a conceptual link between law and moral reasoning. The purpose of this paper is to redirect Dworkin's theory to an unlikely wanted spot for him: the renewal of positivism with its main goal to separate both realms (law and morality). The strategy is to make a chirurgical intervention: to transplant concepts from Dworkin's work to positivism, and try to get a compatibility relationship. There is a broad disagreement among legal positivists about this possibility, and there is at least one branch not interested in confronting Dworkin's theory; thus, this article endorses the kind of positivism that could benefit from this operation, a non-casual positivism linked to an ideal of the rule of law. The goal of this paper is to test this complicated transplantation.
\end{abstract}

Keywords:

Legal Positivism, Moral Reasoning, Rule of Law, Legal Methodology, Dworkin, Ronald $M$. 
Esta revista forma parte del acervo de la Biblioteca Jurídica Virtual del Instituto de Investigaciones Jurídicas de la UNAM www.juridicas.unam.mx

http://biblio.juridicas.unam.mx

\section{A SIDE EFFECT OF DWORKIN'S THEORY}

Summary: I. Positivism's Main Flaw. II. What Kind of Flaw is This? Casual Positivism vs non Causal Positivism. III. Overcoming Positivism's Flaw. IV. How to get Positivist Elements from this Theory that Demands Engagement in Moral Reasoning? V. The Requirement of Justification. VI. A Possible Distinction: Internal v. External Principles. VII. Conclusion. VIII. Bibliography.

Is it true that one might only accepts Dworkin's theory if one in turn rejects positivism in its classic conception? And conversely, is it true that one might only accept Hart's positivism if in turn one steps aside from Dworkin's valuable contributions to the building of a legal philosophy self called "non-postivist"? In this paper, I will try to explore one of the possibilities of avoiding this dilemma. The path is simple: we shall try to re-read the Dworkin-Hart debate not only focusing on who makes the best argument to answer the great question of legal philosophy -is there a necessary link between law and morality? - but also on the rest of the philosophical spots. In my view, both philosophers introduce complex bodies of concepts with strong explaining force of their own that might be connected in more than one way for answering different questions of legal philosophy not necessary related to the question so as to the relationship of law and morality. ${ }^{1}$

One of these questions is this: is it possible to recast core dworkinian concepts into positivism in an effort to present this theory "in its best light" or at least in a better one. We know that Dworkin, before presenting his theory of law, in his landmark book Law's Empire, has tried to present positivism in what he considers the most sophisticated version, this is, that of H. L. A. Hart. But this task was then early finished because Dworkin then directed his new set of con-

1 For a discussion on the subject matter, see Number 5 of Problema, Anuario de Filosofía y Teoría del Derecho, UNAM, Instituto de Investigaciones Jurídicas, 2011. 
Esta revista forma parte del acervo de la Biblioteca Jurídica Virtual del Instituto de Investigaciones Jurídicas de la UNAM www.juridicas.unam.mx

http://biblio.juridicas.unam.mx

\section{DAVID GARCÍA SARUBBI}

cepts (constructivist, interpretation, integrity, etcetera) to direct a blatant attack to positivism. My concern is to answer the question whether it is possible to make a further addition to positivism, one Post-Hart, with the same concepts used later to undermine it. This is, could Dworkin before presenting his comprehensive view of law, in an effort to present his opponent in his best light, give it a hand with concepts of his own?

Of course, behind this question it looms the point we wanted to avoid at the outset (the relationship of law to morality) since we are asking about a possible dworkinian account of positivism, this is, about a plausible new or supplemental characterization of a jurisprudential tradition, initiated with Austin and meaningfully developed by Kelsen, that presents a picture of law independent from morality, yet the tradition we have in mind is not the most radical version of exclusive positivism, but that which claims that law is a "limited domain" in contrast with the broad field of practical reasons provided by morality. This looming question, however, shall only be seen indirectly, as we conceive the study of biological organs subject to transplanting; organs as concepts might deserve an independent analysis, even though we know their final destination is to make a body -and not others- work in a certain fashion; the purpose is to try to figure out how it would it be if posited in a different body. Following this metaphor, my purpose is to transplant some Dworkin's concepts to a different jurisprudential repository from which it meant to be part.

It shall not be assumed that this effort implies a discredit of Dworkin position that morality is inherently linked to law, a pervasive point carefully entrenched in his work; that is an impossible task for this paper and it is not my purpose. It is only that I think that positivism is able to compete in a more equal footing in explaining law once we have introduced some dworkinian concepts to help. ${ }^{2}$ By the same

2 Probably this is in the same direction of overcoming a "casual" positivism in the sense argued by Jeremy Waldron. The idea is to deny the 
Esta revista forma parte del acervo de la Biblioteca Jurídica Virtual del Instituto de Investigaciones Jurídicas de la UNAM www.juridicas.unam.mx

http://biblio.juridicas.unam.mx

\section{A SIDE EFFECT OF DWORKIN'S THEORY}

token, I am not thinking Dworkin followers would agree with the use of their concepts here proposed and I assume that their intent is to give them a different direction; but that reinforce the enterprise of this effort: I want to explore whether the limbs that coherently conform this non-positivist tradition, if we propose so, might be isolated and tested to be transplanted to make a different body improves its functioning. At least it is worth trying.

For this exercise, we first need to identify a fundamental premise of positivism (social sources), from where follow what is alleged to be the main theoretical problem (the solution of hard cases); then, we will recreate the response and alternative vision aimed at approaching that gap (law as an interpretive practice where integrity is the goal) and then isolate the concepts upon that narrative is built (personification, internal point of view, interpretation with the three stages in preinterpretive, interpretive and postinterpretive, integrity and justification).

Before intending to translate those concepts to positivism, we need first to recognize the fact there is broad disagreement among this tradition (at least we have in mind casual and non-causal positivism); thus, we might think there is an expression within positivism that is not interested in the dworkinian objection (casual positivism), so we identify the one we have as the candidate of our intellectual transplantation and we find it in the version defended by Jeremy Waldron, which not only affirms itself detaching from causal positivism (the radical version), but because it claims that the concept of law is inherently linked to the ideal of the "rule of law", which in turns presents three branches, formal, procedural and substantive, only the first and the second actually might be linked to positivism and,

general positivist picture traceable to Hobbes that "Law is any system of command with the power to dominate all other system of command in a given society, where the chain of effective command can be traced to a single politically ascendant source". See "The Concept and the Rule of Law", Georgia Law Review, Vol. 43, No. 1, pp. 3-54, fall 2008. 
Esta revista forma parte del acervo de la Biblioteca Jurídica Virtual del Instituto de Investigaciones Jurídicas de la UNAM www.juridicas.unam.mx

http://biblio.juridicas.unam.mx

\section{DAVID GARCÍA SARUBBI}

thus, get a profit from this exercise, since the substantive ideal of the rule of law is one with strong moral claims, and lead us to Dworkin's position (in one of its different expressions), that is to say, to the jurisprudential tradition that links law to morality in a strong sense.

To test the transplanting of theses core dworkinian concepts we need to finds formal fundamental similarities with the basic structure of positivism - so they need be compatible prima facie - and then insulate the component where necessary engagement in moral reasoning resides in Dworkin's theory; for that end it will be introduced an philosophical distinction between "external" and "internal" principles and we will argue that external principles gives coherency to the moral reading of law, whereas, internal principles might work for positivism.

Finally, casted those Dworkin's concepts exclusively in light of internal principles, we will propose a conception of practice of interpretation aimed at integrity consistent with positivism. This conclusion will finally be tested.

Some might replicate that this paper goal is much better achieved by any work explaining "inclusive positivism", that is, the philosophical tradition claiming that law if not necessary moral in substance, yet could introduce moral concepts, because that theory might subscribe some of Dworkin conclusions. Still, this is not a good discredit of this effort, for the purpose of this paper is not to find a branch of positivism that shares with Dworkin theory the explaining of the concept of law, but the more modest objective to explore whether dworkninian concepts might be isolated and transplanted to positivism, just for the sake of the argument as to whether that tradition first targeted to be discredited in Law's Empire as self-defeating, might be compatible with those attacking organs.

\section{Positivism's MAIN FLAW}

Dworkin places the main flaw of positivism in its incapability to explain the role of law in hard cases where there

PROBLEMA

Anuario de Filosofia y Teoría del Derecho, Núm. 8, enero-diciembre de 2014, pp. 307-352 
Esta revista forma parte del acervo de la Biblioteca Jurídica Virtual del Instituto de Investigaciones Jurídicas de la UNAM www.juridicas.unam.mx

http://biblio.juridicas.unam.mx

\section{A SIDE EFFECT OF DWORKIN'S THEORY}

seems to be no rule of decision clearly identified beforehand by "the rule of recognition" described by Hart.

We shall remember that classic positivism purports to explain law as a system of norms derived from "social sources" linked in a coherent way that regulates human behavior objectively, that is to say, by attaching normative solutions to certain courses of actions, capable to be apprehended by a rational legal reasoning and ready to be applied by officials excluding any subjective consideration, as far as we can trace a rule of recognition that say what the law is. When it comes to asking what law demands in particular cases we don't pay attention to all practical reasons speaking to the issue at hand, but only to those legally relevant and referred to by a rule of recognition, from which we get a solution we think of as an authoritative one. This is why law is in a position to claim the place of an independent science, since it is one that studies systematically an ordering of social behavior that is objective, based on the idea of norm created exclusively by human conduct. ${ }^{3}$

However this general claim, Dworkin identifies "hard cases", not really rare that imply the wielding of great amount of power by officials and raise heated public debates in society, cases that some times we appreciate to be core issues for a legal system to resolve, in which positivism just claim there is not law to be applied.

Michael S. Moore identifies four types of hard cases all deriving from the idea advanced by J. L. Austin that "fact is richer than diction". The first is "where there is no obvious law having any bearing on how such cases should be decided"; a second kind also involves a "lack of determinate precedent, but here the lack is not total", since the issue is whether to follow a precedent or to make a distinction of the case at hand, this is, the narrowing or stretching of the holding of a prior ruling; the third kind comes when the law

3 For further reference, see Vázquez, Rodolfo, Entre la libertad y la igualdad. Introducción a la filosofía del derecho, Madrid, Trotta, First chapter, 2006. 
Esta revista forma parte del acervo de la Biblioteca Jurídica Virtual del Instituto de Investigaciones Jurídicas de la UNAM www.juridicas.unam.mx

http://biblio.juridicas.unam.mx

\section{DAVID GARCÍA SARUBBI}

contains two or more legal standards that apply to a given case, "yet these standards require that incompatible legal remedies be given"; finally, the fourth case arises when there is a norm to be applied but it is indeterminate - vagaries in the meanings of terms used in legal standards. ${ }^{4}$

Dworkin points us out that positivism's answer for those cases is that judges have run out of law and then they just exert unfettered discretion based on the power the legal system has given upon them to decide cases. For him, thus, this is the breaking point of positivism because it is incapable of explaining our strong commitment to the opposite assertion, this is, judges apply substantive norms embedded in these cases that many times define important straits in our society.

Frederick Schauer takes on the point "[j]ust as Kelsen emphasized that no legal decision was completely determined by the law, so too can Raz accept that important parts of judicial and legal practice are not based on what the positivist would call law. If one can accept that no legal decision is completely determined by law, one can accept as well that many legal decisions are largely undetermined by law, even though they may determine what the law will be." Because of that, the argument goes, this jurisprudential tradition, as it is defended in general terms, risks to explain too little of the process by which conclusions are reached in legal argument and judicial decisions, "but if too much remains unilluminated we can understand why Dworkin and other would wish to head in a different direction". ${ }^{5}$

We have judges to decide cases, especially those, where there is broad disagreement when it comes to the solution of the issue, and do not reserve them to the political realm because we think the legal material, as a whole, objectively applied, is capable to offer a correct answer and settle the

4 Moore, Michael S., "Law and Morality: Four Reflections on Law and Morality", William \& Mary Law Review, Vol. 48, 2007, pp. 1525-1569.

5 Schauer, Frederick, "The Limited Domain of Law", Virginia Law Review, Vol. 90, 2004, pp. 1910-1955. 
Esta revista forma parte del acervo de la Biblioteca Jurídica Virtual del Instituto de Investigaciones Jurídicas de la UNAM www.juridicas.unam.mx

http://biblio.juridicas.unam.mx

\section{A SIDE EFFECT OF DWORKIN'S THEORY}

disagreement. Thus, Dworkin concludes, there is something wrong in the positivist account since it does not satisfy our understanding of this important point in the social practice of law. Creation of law ex post facto by judges is not the best explanation of what we have in mind when discussing important cases before courts.

Dworkin builds, as we will see later, a complex theory, a non-positivist account of the practice, according to which law exists in these hard cases, based on the idea that judges need to give the best moral reading of the legal material, one that best makes sense of the whole body of precedents, statutes and legal practices, to discover those deep embedded principles of law from which it is possible to derive an objective solution. In this sense, there is not discretion of officials in charge of dispensing cases in the "strong sense" claimed by positivism, but a "weak sense" of that concept, whereby judgment is needed to interpret the law controlling the case at hand.

We could say that Dworkin's theory, however, goes in a sense counter to the main conclusion of the social sources thesis from which this main positivism's flaw is derived: "If a legal question is not answered by standards deriving from legal sources, then it lacks a legal answer", and claims that even in these cases it is possible to get an legal and rational answer, yet not from those political past decisions we refer to as social sources". ${ }^{6}$

Positivism claims that law is originated by social sources and when those sources do not provide a clear answer, then, there is no law to apply, but discretion and unfettered will of officials. Dworkin denies this and suggests judges to extend their legal reasoning beyond those limited borders and make introduce themselves in the moral reasoning realm, one adjusted and intertwined to legal reasoning in where the point is to inquire into the justification of the fabric of law, for in those justifying reasons is to be our an-

6 Raz, Joseph, The Authority of Law, New York, Oxford University Press, 2009, p. 50. 
Esta revista forma parte del acervo de la Biblioteca Jurídica Virtual del Instituto de Investigaciones Jurídicas de la UNAM www.juridicas.unam.mx

http://biblio.juridicas.unam.mx

\section{DAVID GARCÍA SARUBBI}

swers for hard cases. Because Dworkin does not stress the limiting role of the "social souces thesis", he is not considered a classic positivist.

Frederick Schauer claims, in this sense:

Dworkin posits that actual legal argument and actual judicial decisionmaking turn crucially on norms that are not previously part of an identified set of legally recognized legal norms. He argues that the use of norms drawn from the universe of social principles and moral values is so prominent a feature of actual legal decisionmaking that no account of law can be satisfactory unless it explains this phenomenon [...] the idea of a source-based rule of recognition for the moral (and political) principles that pervade the legal decision making is impossible. Thus, he concludes, the looming presence of morality in actual legal decision making is such that neither a rule of recognition nor the idea of law as a limited domain can provide an accurate descriptive account of advanced modern adjudicatory practices. ${ }^{7}$

\section{What Kind of Flaw is This? CASUAL \\ Positivism vs Non CAUsal Positivism}

I find important to make a further distinction here. It is not that positivism does not explain hard cases - ex post facto creation of law is a theoretical answer-, but instead that it explains it counter to our most basic notion that it is not for law to be created and applied retroactively (in such a case, this shall be labeled as a defect), a feature that is central to the ideal of the rule of law, mostly defended by legal theories we cherish to explain our social and political order, yet not necessarily linked to a substantive moral tradition, that is to say, we tend to explain our concept of law in relation with the social function it deploys and from there we find that ex post facto law is incompatible with the idea to be ruled by law.

7 Schauer, Frederick, "The Limited Domain of the Law", Virginia Law Review, Vol. 90, 2004, p. 1909. 
Esta revista forma parte del acervo de la Biblioteca Jurídica Virtual del Instituto de Investigaciones Jurídicas de la UNAM www.juridicas.unam.mx

http://biblio.juridicas.unam.mx

\section{A SIDE EFFECT OF DWORKIN'S THEORY}

As John Finnis claims, one thing is to ask "is this really a law?" and other, more abstract and philosophical "what is law?", that latter concerning its meaning, its fidelity to law's purpose, its role in sound legal reasoning, its legal effects, and its social functions, questions we shall answers not only by referring to the dimension of legal validity, but the concept of law from an interpretive perspective. This way of inquiry is first recommended by Aristotle, again Finnis remind us, whereby the methodology is interested in the "why" of legal systems. "[N]atural sciences including a part of the science of psychology, human actions, practices, dispositions and the discourse constitutive of some such practices cannot be understood without understanding their point, objective, significance or importance as conceived by the people who perform them, engage in the etcetera". ${ }^{8}$

It is not that the ex post facto answers be excluded as completely wrong, but we think of law in general terms due to a different perspective, this is, as a social tool that conceptually is the only way to achieve the rule of law whereby judges are to decide hard cases because they apply norms to settle controversies, not because they are in a moral position to introduce their personal opinions for they to settle cases unrestrained; that is the minimal and institutional purpose of law, and the starting place where we discuss that concept from an internal point of view; if a considerable range of cases is not determined by law in a strong sense, and they just go merely as a legal authorization for judges to go either way, then, our commitment with the entire enterprise to have a government of law and not of persons will lack theoretical underpinnings.

From the opposite perspective, under what Waldron has called casual positivism, hard cases are subject to a very straightforward explanation: law, as Kelsen has said, is what it is produced according to higher conditioning norms that in turn were created under the auspices of higher

8 Finnis, John, "Law and What I Truly Should Decide", The American Journal of Jurisprudence, Vol. 48, 2003, pp. 107-129.

PROBLEMA 
Esta revista forma parte del acervo de la Biblioteca Jurídica Virtual del Instituto de Investigaciones Jurídicas de la UNAM www.juridicas.unam.mx

http://biblio.juridicas.unam.mx

\section{DAVID GARCÍA SARUBBI}

norms finally traceable to a fundamental norm. 9 The rules of decision given by judges in hard cases are law because they are legalized by legal procedures or produced accordingly to "secondary rules" that "provide the centralized official 'sanctions' of the system". ${ }^{10}$ For this conception, retroactivity is a contingent fact in any legal system, not related directly with the identity of law. ${ }^{11}$ Ex post facto law is not a failure of the theory, it is a fact clarified by the neutrality of legal science.

I sustain that when Dworkin replies that this is not a good explanation of what is really going on within legal systems, the conversational partner interested in this critic is not this kind of casual positivism referred and then replied by Waldron, but instead that which, undertaking the social source thesis as well, defends a conception of law that is equalized to the ideal of "the rule of law", and thus, keeps with the idea that law is different from a mere rationalized chain of commands, even in hard cases.

For this non causal positivism, the concept of law is not detached from the ideal of the rule law, since it takes to be a fact that law is a social technique and then we need to incorporate this functional perspective in our intellectual endeavor. We have law to establish a social order based on it for ruling; if law is not to have central place as reference for disputes, coordination and order in this strong sense (the main function of law as settlement of disagreement) then the reflection on the concept becomes futile. So we take for granted that the rule of law and the concept of law come in a package.

9 Kelsen, Hans, Pure Theory of Law, translated by Max Knight, Berkeley and Los Angeles, University of California Press, pp. 193-276, 1967.

10 Hart, H. L. A, The Concept of Law, 2nd. ed., Oxford and New York, Oxford University Press, p. 98, 1994.

11 However, it is not clear if under this casual positivism a great amount of retroactive law could compromise the effectiveness of the legal order and then the validity of the legal system. 
Esta revista forma parte del acervo de la Biblioteca Jurídica Virtual del Instituto de Investigaciones Jurídicas de la UNAM www.juridicas.unam.mx

http://biblio.juridicas.unam.mx

\section{A SIDE EFFECT OF DWORKIN'S THEORY}

It is not to resign to the goal of objectivity and neutrality of legal philosophy and to introduce substantive elements to be advanced by legal philosophy — specially, because we consider the formal conception of the rule of law, which is no interested in the content of the legal system-, but instead to suggest that legal philosophy, as Hart defends, needs to take into account its social function (its point), just like tools are explained it the way they are used without abandoning explanatory force; a view, as Tom Campbell discuss, moves between a descriptive and normative dimensions, still does not purports to discuss mere morality. ${ }^{12}$

Yet there are those causal positivist, who as Kelsen, will defend the purity of the concept of law, and will defend its difference with the ideal of the rule of law. For they, ex post facto creation of law still is the best explanation of hard cases because they are no interested in the achievement of the ideal interconnected; still, there are those who believe law is a concept central for the rule of law and cannot be divided. For those who defend the latter conception and, at the same time, claim the separation of law and morality, is this exercise of transplantation directed.

Joseph Raz discuss the ideal of the rule of law and claims it comprises ideals and a constellation of values in political morality, such as rights, social justice, democracy, thus, there are those defending a substantive conception of this ideal. For this vision, to have a rule of law is to have a system of property rights, for example, that helps to have a social ordering where government is not allowed to intervene by distributive policies, ${ }^{13}$ or those, as Dworkin, who claim the rule of law is a system whereby citizen claim moral rights against government, who in turn is obliged to

12 Campbell, Tom, "Rewriting Hart's Postcript: Thoughts on the Development of Legal Positivism", Problema. Anuario de Filosofía y Teoría del Derecho, México, núm. 5, 2011, pp. 23-52.

13 See, for example, A. V. Dicey (Law of the Constitution) and F. A. Hayek (The Road to Serfdom). 
Esta revista forma parte del acervo de la Biblioteca Jurídica Virtual del Instituto de Investigaciones Jurídicas de la UNAM www.juridicas.unam.mx

http://biblio.juridicas.unam.mx

\section{DAVID GARCÍA SARUBBI}

respect that cluster of rights notwithstanding how important social goal are to the contrary.

However, there are those as Fuller or Raz himself, who believe the rule of law is an ideal more restricted, concerned exclusively with the formal goal of achieving the guiding of conduct by law, in where social goals are immaterial; for them, as Brian Tamanaha argues, this ideal "requires that government officials and citizens are bound by and act consistently with the law", for whom this narrow definition is preferable "because it represents a common baseline that all of the competing definitions of the rule of law share [...] this version is amenable to a broad range of systems and societies". 14

For this formal perspective, if law is to govern humans as such, it needs to deploys features to guide human conduct and those features conditioned the façade of any jurisprudential tradition; independently of the laundry list every philosopher defends, we take the idea that inspires them at the bottom. Retaking Tamanaha: "[t]his basic requirement entails a set of minimal characteristics: law must be set forth in advance (be prospective), be made public, be general, be clear, be stable and certain, and be applied to everyone according to its terms. In the absence of these characteristics, the rule of law cannot be satisfied". ${ }^{15}$

This formal conception of law is restricted and limited by very few structural conditions, thus, compatible with totalitarian regimes and with a myriad types of political structures; all it requires is that legal rules be at the center for guidance and ruling. Nonetheless, it rejects ex post facto creation of law in hard cases, specially, is retaking Schauer, within that category, much of law remains unilliminated, since it would come afoul of its main objective of guiding conduct; thus, this formal conception of the

14 Tamanaha, Brian, "A Concise Guide to the Rule of Law", St. John's University, paper 07-0082, September 2007.

15 Idem. 
Esta revista forma parte del acervo de la Biblioteca Jurídica Virtual del Instituto de Investigaciones Jurídicas de la UNAM www.juridicas.unam.mx

http://biblio.juridicas.unam.mx

\section{A SIDE EFFECT OF DWORKIN'S THEORY}

rule of law is quite interested in Dworkin objection and is interested in improving its theory.

In other words, for those defending a positivism different to its casual expression, law is a technique of control that subjects individuals to the "government of law and not of men" and casual positivism, at least explaining hard cases, render a government of men, since law in here implies necessarily the empowerment of judges to decide important issues according to their own personal preferences. This kind of non casual positivism (positivism that cares about the ideal of the rule of law) tries to develop more deeply and in a substantively better way the kelsenian "Identification Thesis" according to which every disposition of cases by judicial officials is covered by law, traceable in one way or another to a social source but not in the weak sense of "solutions coming from procedural forms" but because solutions are determined by the legal system even in those cases where at first sight judges seem to decide with a free hand.

Under this kind of theory (interested in law as effective check or limitation of power), once more, Lon Fuller, one vibrant defender of this philosophy, would say that law is the body of norms that comply with the requirements of generality, publicity, prospectivity, clarity, consistency, practicability, constancy and congruence. Law as a framework of government which allows the achievement of political goals by treating humans with dignity, this is, as active agents capable of planning and of intelligent behavior; once more, this is a argument in favor of law directed to the guiding and ordering of society. 16

If law is created retroactively at will by judges every time there is a hard case (which for Dworkin are fundamental cases in law, since they shape the legal order), then law is

16 See Waldron, Jeremy, "Retroactive Law: How Dodgy was Duynhoven?", Otago Law Review, Vol. 10, No. 4, 2004, pp. 631-654, and Fuller, Lon, "The Morality of Law", Revised Edition, Yale University Press, New Haven, 1969. 
Esta revista forma parte del acervo de la Biblioteca Jurídica Virtual del Instituto de Investigaciones Jurídicas de la UNAM www.juridicas.unam.mx

http://biblio.juridicas.unam.mx

\section{DAVID GARCÍA SARUBBI}

self defeating, for it's failing to regulate human behavior respecting the agency or dignity of humans beings. ${ }^{17}$

At least, that is the kind of positivism to which I am trying to recast some of Dworkin's concepts, one that keeps the "separation" and "social sources" thesis, at the same time, they defend a formal conception to the rule of law. ${ }^{18}$

Finally, it needs to be noticed, once more, that casual positivism might replicate to defend the ex post facto answer on behalf of a neutral perspective not only descriptive but normative also; as Frederick Schauer reminds us "if we go back to the earliest traces of positivism, we see that Hobbes, like Bentham and Austin, thought it important in actual legal systems to be able to identify the law from among a much larger domain of social, moral, and political norms [...] Indeed, positivism's roots become even more important once we recognize that, for Bentham and Hobbes, legal positivism had a prescriptive function as well as a descriptive one. [...] For Bentham, the domain of the law was not only something to be identified and described, but was also the domain within which judges were to be corralled. [...] Moreover, a different form of the prescriptive side of positivism defends positivism as the best way of offering a strong critique of law". ${ }^{19}$

Keeping apart methodological positivism from political morality helps to foster moral reasoning, since once we

17 Of course there are occasions where judges, even on this version, create law retroactively and this is seen beneficial for the rule of law (for example when updating law to social norms), however, retroactive law is here condemned in the understanding that it is the default rule in hard cases with systematic implication for the entire legal system. Idem.

18 This non casual positivism in still compatible with the social thesis because, as Raz claims, it is still an "open question whether or not those social facts by which we identify the law or determine its existence do or do not endow it with moral merit", further more, whether as a matter of general conditions of human existence, legal systems "of necessity conform to some moral values and ideals". The Authority of Law, p. 39.

19 Schauer, Frederick, "The Limited Domain of Law". Virginia Law Review, Vol. 90, No. 7, 2004. 
Esta revista forma parte del acervo de la Biblioteca Jurídica Virtual del Instituto de Investigaciones Jurídicas de la UNAM www.juridicas.unam.mx

http://biblio.juridicas.unam.mx

\section{A SIDE EFFECT OF DWORKIN'S THEORY}

have identified what the law is, then, me must decide, hopefully by open reasons, if law deserves obedience or not. Law in a strong sense does not determine hard cases, but that is not a sign of approval, but the starting point for that practice to be identified, as a realm of power for judges, and then, to keep power accountable or subject to a different legal design. ${ }^{20}$

Even if we concede the rule of law is an ideal of political morality, it is limited to an formal ideal, which turn it compatible with a myriad of systems; all it claim is that features needed to guide human conducts shall to be considered in any decent legal philosophy. Hart conceded this. Not explicity, but somehow discussing the ideal: "If social control of this sort is to function, the rules must satisfy certain conditions: they must be intelligible and within the capacity of most to obey, and in general they must not be retrospective, though exceptionally they may be [...] Plainly these features of control by rule are closely related to the requirements of justice which lawyers term principles of legality". Here, legality is proposed to be translated to the rule of law in its formal version. And Hart concludes: "Again, if this is what the necessary connection of law and morality means, we may accept it. It is unfortunately compatible with very great iniquity." 21

Here, Jules Coleman would claim "the morally attractive property of law is its inherent potential to realize or to manifest an ideal of governance", this is not to say more that law, by its nature, has the inherent capacity to realize certain moral ideals by making the guiding of human conduct possible in some way. ${ }^{22}$ Just in this limited sense we take

20 Bobbio, Norberto, El problema del positivismo juridico, trans. Ernesto Garzón Valdés, México, Fontamara, 1991.

21 Hart, H. L. A., The concept of Law, 3rd. ed., Oxford, Oxford University Press, 2012, pp. 206 y 207.

22 Coleman, Jules, The Practice of Principle: In Defense of a Prgamatist Approach to Legal Theory, Oxford, Oxford University Press, 2001. 
Esta revista forma parte del acervo de la Biblioteca Jurídica Virtual del Instituto de Investigaciones Jurídicas de la UNAM www.juridicas.unam.mx

http://biblio.juridicas.unam.mx

DAVID GARCÍA SARUBBI

non casual positivism as attached to the formal ideal of the rule of law.

\section{Overcoming Positivism's Flaw}

In general, Dworkin's answer is that "[1]egal practice, unlike many other social phenomena, is argumentative." This is because at the bottom, lawyers and judges debate about the very grounds of law. He calls this a theoretical disagreement, the main topic of which is "whether statute books and judicial decisions exhaust the pertinent grounds of law". 23

The main flaw of positivism in general is that it evades this theoretical disagreement by claiming that "genuine disagreement about what the law is must be empirical disagreement about the history of legal institutions"24. In other words, disagreements about what past decisions of political authorities amount to. But, as he further contends, in the most fundamentals and relevant cases of law, the solution is not entirely traceable to any past decision of any political institution and then the historical researching of political decisions is quite insufficient. But if the solution for hard cases is not in a past political decision, then where is it?

Dworkin's response has a high complex structure, but for the present purposes, only matters to remark the following: law is an argumentative practice (linked to a notion of associative obligation or relationship) upon which participants have a constructive interpretive attitude which push them to inquire into the point of the preinterpretive material (statutes, books, precedents etcetera) that conform past political decisions; for it is the justification of past decisions we acknowledge as good law. We all live against a background of institutional arrangement which we need to consider in our decisionmaking process as long as we decide to

23 Dworkin, Ronald, Law's Empire, Cambridge, Massachussets, Harvard University Press, 1986, p. 13.

24 Ibidem, p. 33. 
Esta revista forma parte del acervo de la Biblioteca Jurídica Virtual del Instituto de Investigaciones Jurídicas de la UNAM www.juridicas.unam.mx

http://biblio.juridicas.unam.mx

\section{A SIDE EFFECT OF DWORKIN'S THEORY}

live together. This argumentative practice, as long as is directed to the point, purpose or value of the preinterpretive material, will lead the participants not only to make sense of the whole body of legal material but to present that material in the best light available, which is to say, to link past decisions with moral principles embedded very deeply in the fabric of law. ${ }^{25}$ "Value and content have become entangled" precisely because of the argumentation to which participants need to engage in. ${ }^{26}$

The main concept in this account is integrity, not only thought of as a requirement of formal consistency and congruence, but as a requirement of substantive congruence between content(s) and value(s). Past decision, then, might be stretched or narrowed in light of these principles and the outcomes of such argumentative procedures are controlling to the solution of hard cases. "Interpretation folds back into the practice, altering its shape, and the new shape encourages further reinterpretation, so the practice changes dramatically, though each step in the progress is interprettive of what last achieved". ${ }^{27}$

For Dworkin, this theoretical framework is translated into an operative test for ordinary legal reasoning. Dworkin claims that this constructive interpretation needs to satisfy a threshold of two requirements in order to render truthfully propositions of law: 1) fitting and 2) justification. The point of the former is to keep faith with past decisions of authoritative sources (such as legislature and judges) and

\footnotetext{
25 Put in a different way, as Gerald J. Postema says, Dworkin's theory is based on three claims: 1) law is an interpretive concept, 2) law itself is a interpretive practice that is characterized as one that is constructive, and 3 ) the sense of the constructive interpretation of the practice of law is to keep faith with the value of integrity that derives from the importance of the kind of associative obligation in virtue of which we engage in that practice (this conforms a community of principles). See "Protestant Interpretation and Social Practices", Law and Philosophy, Vol. 6, No. 3 Dworkin's “Law's Empire”, 1987, pp. 287-319.

26 Ibidem, p. 48.

27 Idem.
} 
Esta revista forma parte del acervo de la Biblioteca Jurídica Virtual del Instituto de Investigaciones Jurídicas de la UNAM www.juridicas.unam.mx

http://biblio.juridicas.unam.mx

\section{DAVID GARCÍA SARUBBI}

the second to make sense of this material in its best light, this is, according to the principles that justify and best explain the content of those decisions. Dworkin claims that judges engage their own moral reasoning in this second stage. This is because there is more than one possible way of making sense of legal material and then the tie-breaker of legal interpretation resides in the merits of the justification made by participants. However, it needs to be remarked that this is not a free-hand for judges - just the way causal positivism defends when it comes to decide hard cases - since integrity demands faith with the entire legal material and compliance with those principles living under the surface of law, yet discoverable through constructive interpretation.

This account explains, unlike positivists, the role of law in hard cases: although there is not a clear rule of decision beforehand in this sort of cases, participants engage in a practice of constructive interpretation whereby they might objectively justify legal decisions by showing a sufficient degree of fitting with past decisions and a convincing justification of it in light of moral principles embedded in the practice as a whole. This argumentation not only is relevant in hard cases, but pervasive to the whole legal practice, only being more evident in the former.

\section{How to Get Positivist Elements from this Theory that Demands Engagement in Moral Reasoning?}

As said at the outset, one common view of Dworkin's theory is that his concepts form a closed linked chain otherwise with not explaining force if not directed to the conclusion that the practice of law necessarily demands a personal engagement in moral reasoning. And there are good reasons to be so. But my purpose in the following pages, I insist, is to deliberately recast some of his concepts to reach not such conclusion. Of course I know this goes counter to his main and explicit purpose of convincing that 
Esta revista forma parte del acervo de la Biblioteca Jurídica Virtual del Instituto de Investigaciones Jurídicas de la UNAM www.juridicas.unam.mx

http://biblio.juridicas.unam.mx

\section{A SIDE EFFECT OF DWORKIN'S THEORY}

the argumentative nature of law implies a link between law and morality. In Dworkin words: "legal argument is a characteristically and pervasively moral argument". ${ }^{28}$ But I think that his main premise, that law is an argumentative practice, does not necessarily draws the conclusion that both realms come to a link if, as I am trying to do, redirected under non-casual positivist premises (only interested in the formal conception of the rule of law).

Here, it comes the task of isolating those non positivist concepts, and finding the formal similarities with positivist fundamental premises; for our purpose, this is no sufficient to conclude the success of the transplantation, so further we need the distinction between "internal" and "external" principles, from which we draw the main force driving the functioning of those concepts in their new jurisprudential body.

The concepts to be isolated are: personification, internal point of view, interpretation, and integrity; the idea is to draw in their similarities and features capable to fit within positivisms.

\section{Personification}

The idea of personification, which is necessary for integrity, defends that law speaks with one voice "as if a political community really were some special kind of entity distinct from the actual people who are its citizens" 29 "because it assumes that the community can adopt and express and be faithful to principles of its own, distinct from those of any of its officials or citizens as individuals". ${ }^{30}$ Then, in hard cases, officials do not enjoy of a license to decide based on their subjective preferences, but to make the best of the princi-

28 Dworkin, Ronald, "Hart's Postcript and the Character of Political Philosophy", Oxford Journal Legal Studies, Vol. 24, No. 1, 2004, p. 4.

29 Dworkin, Ronald, Law's Empire, Cambridge, Massachussets, Harvard University Press, 1986, p. 168.

30 Ibidem, p. 172. 
Esta revista forma parte del acervo de la Biblioteca Jurídica Virtual del Instituto de Investigaciones Jurídicas de la UNAM www.juridicas.unam.mx

http://biblio.juridicas.unam.mx

\section{DAVID GARCÍA SARUBBI}

ples binding the community through. It is not judges as individuals speaking but the intermediaries of a community of principles.

I find this familiar to positivism. Kelsen, for example, claims that every individual application of a norm has to be attributed to the community that the law creates, in Kelsen words, "which is a figurative expression of the mental operation by which we refer the coercive act prescribed by the legal order to this legal order, the unity of which we personify as an acting entity" 31 .

Moreover, this personification idea is explored by Kelsen in his theory of the state, and argues that law creates a juridical community, outside of which in senseless to speak of powers, officials and government, so it is the law as an entity that gives existence to the political community; American law, German law and Mexican law as existing persons, law personification whereby to law and political power are equated. ${ }^{32}$

The acceptance of this, which we can refer as the "identification thesis", has a central importance to positivism because it grounds the assertion that law has an independent existence. Law is everything that is enacted, applied or produced within that entity. Kelsen established the following distinction based on this idea: "The sentences by which the science of law describes these norms [legal] and relationships must be distinguished as "rules of law" from the legal norms that are created by the legal authorities, applied by them, and obeyed by legal subjects". ${ }^{33}$

The notion of personification is important not only for the idea of integrity, but also as an essential feature of any legal practice: its authoritative character whereby it disposes of social disagreement. In this respect, it is worth noticing

31 Kelsen, Hans, Pure Theory of Law, translated by Max Knight, Berkeley and Los Angeles, University of California Press, 1967, p. 34.

32 Kelsen, Hans, Teoría general del derecho y del Estado, Trans. Eduardo García Máynez, Mexico, Imprenta Universitaria, 1949.

33 Ibidem, p. 70. 
Esta revista forma parte del acervo de la Biblioteca Jurídica Virtual del Instituto de Investigaciones Jurídicas de la UNAM www.juridicas.unam.mx

http://biblio.juridicas.unam.mx

\section{A SIDE EFFECT OF DWORKIN'S THEORY}

that the personification's idea involves the principle of settlement that Waldron identifies as a rule-book element of Dworkin. This principle of settlement is, as we know, a touchstone idea of positivism. ${ }^{34}$ The settlement is possible because it is attributed to what we call law, different in nature from the rest of mechanisms of solution in society.

\section{Internal Point of View}

At the beginning of Law's Empire, Dworkin says the following: "This book takes up the internal, participant's point of view; it tries to grasp the argumentative character of our legal practice by joining that practice and struggling with the issues of soundness and truth participants face". 35 Then, to get to the idea of law, not only we need to conform with the registration of empirical regularity of conducts in light of certain rules or standards, but to have law as a reservoir of reasons from where to involve into a practice where participants give and receive reasons of some sort y take certain courses of actions.

John Finnis argues that this concept suggests us to think about law from the internal point of view that proves to be simple, "his, yours, mine, not because they are his, yours or mine, but because it seems true to him, you and me, that there is value in having the rules at stake, reason for having them". ${ }^{36}$

This methodological tool, however, is not new and certainly not foreign to positivism. ${ }^{37} \mathrm{H}$. L. A. Hart considered it

34 Waldron, Jeremy, "The Rule of Law as a Theater of Debate", Dworkin and his Critics: with Replies by Dworkin, Edited by Justine Burley, Oxford, Blackwell Publishing, 2004, p. 331.

35 Dworkin, Ronald, Law's Empire, Cambridge, Massachussets, Harvard University Press, p. 14, 1986.

36 Finnis, John, "Law and What I Truly Should Decide", The American Journal of Jurisprudence, vol. 48, 2003, pp. 107-129.

37 I think this is also included in the social sources thesis of Raz, when he says that this implies that "Law is a public measure by which one can 
Esta revista forma parte del acervo de la Biblioteca Jurídica Virtual del Instituto de Investigaciones Jurídicas de la UNAM www.juridicas.unam.mx

http://biblio.juridicas.unam.mx

\section{DAVID GARCÍA SARUBBI}

the most essential key to understand, from a purported sociological descriptive standing point, the social function of law: he was the first positivist that claimed that it is the crucial key element for differentiating between "observable regularities of conduct, predictions, probabilities and signs" and the working of legal norms or "rule-dependant notions of obligation or duty". 38

Hart claims that law is not comprised of rules over which people converge, but instead of standards for critical appraisal of behavior (internal aspect) taken for their sake as reasons to react in certain ways otherwise non understandable (internal point of view). ${ }^{39}$

Legal norms are not predictive statements but standards for social assessments. "[W]here there is such a rule deviations are generally regarded as lapses or faults open to criticism, and threatened deviations meet with pressure for conformity, though the forms of criticisms and pressure differ with different types of rule". ${ }^{40}$ Law is not understandable or learned by the notion of general habit of obedience (mere convergence of behavior, which is the external aspect), but by the internal point of view, whereby "we can, in a sense,

measure one's own as well as other people behaviors". This kind of public measure goes beyond the idea of commands given by a sovereign, as the outcome of a specific will, but rather a measure connected in a wider net of ideas traceable at least theoretically to a broad vision. In Raz words: "It is an essential part of the function of law in society to mark the point at which a private view of members of the society, or of influential sections or powerful groups in it, ceases to be their private view and becomes a view binding on all members notwithstanding their disagreement with it" The regulation achieved by law does not depend only on its motivation by coercion, but primarily by the establishment of common patterns that allow cooperation among individuals. See Raz, Joseph, The Authority of Law, p. 51.

38 Hart, H. L. A., The Concept of Law, 3rd. ed., Oxford, Oxford University Press, 2012, p. 88.

39 Ibidem, p. 11.

40 Ibidem, p. 55.

PROBLEMA

Anuario de Filosofia y Teoría del Derecho, Núm. 8, enero-diciembre de 2014, pp. 307-352 
Esta revista forma parte del acervo de la Biblioteca Jurídica Virtual del Instituto de Investigaciones Jurídicas de la UNAM www.juridicas.unam.mx

http://biblio.juridicas.unam.mx

\section{A SIDE EFFECT OF DWORKIN'S THEORY}

subtract the sanction and still leave an intelligible standard of behavior which it was designed to maintain". ${ }^{41}$

For Hart the internal point of view sheds light over the way by which law accomplishes the task of control: "The principal functions of the law as a means of social control are $[\ldots]$ to be seen in the diverse ways in which the law is used to control, to guide, and to plan life out of court". ${ }^{42}$

What it is important here is that the acceptance of the internal point of view is not, at might appear at first sight, an invitation to bring about external moral values into legal reasoning that in some way justify the legal practice, but instead, a "critical reflective attitude to certain patterns of behavior as a common standards". ${ }^{43}$ Norms are understood as standards and then assimilated to reasons for criticism and all this establish a plateau from which law flows to an argumentative practice, not necessarily moral in nature.

It is important to notice, that the internal point of view is a benchmark for a new kind of positivism, separated from Austin and Kelsen. As Brian Bix claims "[a]s against earlier legal positivists like John Austin and Jeremy Bentham, Hart was offering a theory that worked harder to explain the normative (rule-following) nature of law, primarily by taking into account the perspective of participants within the legal system". ${ }^{4}$

Yet, for those defending casual positivism, this internal point of view might appear be an element not needed for the purity of the theory of law, since this could be an requirement for the efficiencency of the social practice, but not related to the notion of law as an group of rules traceable to a fundamental norm. This is not the case, for non casual positivism attached to the formal ideal of the rule of law, for here law is called to establish a legal order for social con-

41 Ibidem, p. 35.

42 Ibidem, p. 40.

43 Ibidem, p. 57.

44 Bix, Brian \& Coleman, Jules, "Legal Positivism, and Legal Authority”, Quinnipiac Law Review, Vol. 16, No. 241, 1996. 
Esta revista forma parte del acervo de la Biblioteca Jurídica Virtual del Instituto de Investigaciones Jurídicas de la UNAM www.juridicas.unam.mx

http://biblio.juridicas.unam.mx

\section{DAVID GARCÍA SARUBBI}

trolling, and then, the internal point of view is an essential for the achievement of the authority of law in social disputes, especially in hard cases, where we discuss about the right decision and we don't get satisfied only by identifying who is to make the decision; we care about the outcome for the sake of the internal point of view. Once more, it is to get the underpinning for a government of law and not of people.

\section{Interpretation}

Dworkin distinguishes creative interpretation from what he calls conversational and scientific interpretation. The difference is that the former aims "to interpret something created by people as an entity distinct from them, rather than what people say [...] or events not created by people." 45 The main concern of creative interpretation is with purposes rather than mere causes. ${ }^{46}$ And those purposes, as long as the subject matter is separated from its author, might be different from the causal intents. The idea is to present what is interpreted in its best light. This kind of interpretation is proper in legal practice.

As far as law is concerned, Dworkin points out to three stages in interpretation: 1) a preinterpretive stage, in which raw legal material subject to further interpretation is identified in broad and in non controversial terms, 2) an interpretive stage at which it is settled some general justification for the main elements of law"47 and 3) a postinterpretive stage or reforming stage "at which he adjust [the participant] his

45 Dworkin, Ronald, Law's Empire, Cambridge, Massachussets, Harvard University Press, p. 50, 1986.

46 Ibidem, 51.

47 Here it is important to notice that "[t]he justification need not fit every aspect or feature of the standing practice, but it must fit enough for the interpreter to be able to see himself as interpreting that practice, not inventing a new one. Ibidem, p. 66. 
Esta revista forma parte del acervo de la Biblioteca Jurídica Virtual del Instituto de Investigaciones Jurídicas de la UNAM www.juridicas.unam.mx

http://biblio.juridicas.unam.mx

\section{A SIDE EFFECT OF DWORKIN'S THEORY}

sense of what the practice 'really' requires so as better to serve the justification he accepts at the interpretive stage". ${ }^{48}$

It seems that Dworkin attaches the greater degree of creativeness in the last stage only, since he claims that in the first two there shall be a certain degree of consensus or deference because otherwise the practice could not take place at all or bare creativeness would be undistinguishable from real interpretation. ${ }^{49}$

Cast in these simplistic terms, it seems that this model of interpretation does not in automatic demands a personal engagement in moral reasoning. All what it demands is to acquire a internal point of view (a critical one) from which to perceive norms as standards of conduct and to push further to inquire into their purposes (which also are deferential to social sources, this is to say, purposes formulated in no controversial terms), and from this point the forming of a proposition of a certain stretching or narrowing of pre-existing legal material. Only in this third stage participants engage in moral reasoning and we need to try to translate this moral model to a positivist one. In the following pages I'll try to insulate those elements in Dworkin's work that reject this formal model and demand an engagement in moral reasoning. For Dworkin, every inquiry for the justification of a social practice demands a personal engagement in moral reasoning; yet, my point is we can have this inquiry in a weak sense that is compatible with non causal-positivism.

\section{A. The Preinterpretive Stage}

In this stage by virtue of a more or less large social consensus it is possible to identity the rules and standards

48 Idem.

49 The main dichotomy under this model is that between concept and conception, being the second a development of abstractions widely accepted in the former. Supporting this, he introduces into his account the idea of paradigm (a set of ideas widely accepted into the community), which would come to provide with a sort of muster to reject interpretations as not sound. 
Esta revista forma parte del acervo de la Biblioteca Jurídica Virtual del Instituto de Investigaciones Jurídicas de la UNAM www.juridicas.unam.mx

http://biblio.juridicas.unam.mx

\section{DAVID GARCÍA SARUBBI}

that might provide with the material for true propositions of law. In one aspect, this stage matches roughly the social sources thesis's claims that law is identified by reference to certain institutional sources of empirical character. One expression of the social source thesis is that this identification of law might amount to a great degree of agreement and in this the Dworkinian preinterpretive stage matches: "Law cannot flourish as an interpretive enterprise in any community unless there is enough initial agreement about what practices are legal practices so that lawyers argue about the best interpretation of roughly the same data". ${ }^{50}$

Raz defends the social thesis as one directed mainly to the identification of social institutions as the sources of law and this is pretty much supported by the following assertion of Dworkin: "Our culture presents us with legal institutions and with the idea that they form a system". ${ }^{51}$ I think, in addition, that Dworkin would not disagree completely with Hart, when the latter claims that this preinterpretive and non-controversial legal material, once identified, "is characterized by a certain kind of supremacy within its territory and independence of other systems".52 This preinterpretive legal material would also present the characteristics of continuity and persistence ${ }^{53}$ and would come "supported by serious social pressure". 54

Moreover, we could say that when Dworkin is referring to a more or less broad agreement about the scope and content of preinterpretive legal material, he is implying that the participants "use as a criterion a fundamental rule or rules of what is to count as law which embraces past as well as present legislative operations" 55 -A rule of recognition that

50 Ibidem, pp. 90-91.

51 Ibidem, p. 91.

52 Hart, H. L. A., The Concept of Law, third edition, Oxford, Oxford University Press, 2012, p. 24.

53 Ibidem, p. 51.

54 Ibidem, p. 88.

55 Ibidem, p. 65.

PROBLEMA

Anuario de Filosofia y Teoría del Derecho, Núm. 8, enero-diciembre de 2014, pp. 307-352 
Esta revista forma parte del acervo de la Biblioteca Jurídica Virtual del Instituto de Investigaciones Jurídicas de la UNAM www.juridicas.unam.mx

http://biblio.juridicas.unam.mx

\section{A SIDE EFFECT OF DWORKIN'S THEORY}

"specify some feature or features possession of which by a suggested rule is taken as a conclusive affirmative indication that it is a rule of the group to be supported by the social pressure it exerts". ${ }^{56}$ In broad terms, this Dworkinian concept is compatible with Hart's postscript disclaimer that the rule of recognition is not to determine completely the legal result in particular cases, but instead its function is "to determine only the general conditions which correct legal decisions must satisfy in modern systems of law". ${ }^{57}$

\section{B. The Interpretive Stage}

The interpretive stage, accordingly, would take place as well in a relatively non-controversial context. In this participants shall be able to recognize general purposes or justifications of the raw material identified in the preinterpretive stage. This, in my view, is also reconcilable with positivist premises, because this agreement is traceable to a common criterion compatible within the rule of recognition, which not only needs to include historical facts or pedigree marks but might incorporate principles of justice or substantive moral values, posited by social sources. ${ }^{58}$ Hart claims the signaling of those principles presupposes by necessity the existence of the rule of recognition, because in turn "presupposes the identification of the settled law, and for that to be possible a rule of recognition specifying the sources of law and the relationships of superiority and subordination holding between them is necessary". 59

56 Ibidem, p. 95.

57 Ibidem, p. 58. This is more or less the same point made by Hart himself when replying in his postscript: "whatever differences may remain between rules and the 'assumptions', and 'consensus' and 'paradigms' of which Dworkin speaks, his explanation of the judicial identification of the sources of law is substantially the same as mine". Ibidem, p. 267.

58 Ibidem, p. 247.

59 Ibidem, p. 265. 
Esta revista forma parte del acervo de la Biblioteca Jurídica Virtual del Instituto de Investigaciones Jurídicas de la UNAM www.juridicas.unam.mx

http://biblio.juridicas.unam.mx

\section{DAVID GARCÍA SARUBBI}

Then, again, the interpretive stage is not foreign to positivism. As Hart says: "when particular statutes or precedents prove indeterminate, or when the explicit law is silent, judges do not just push away their law books and start to legislate without further guidance from the law" (emphasis added). It is worth remembering that Dworkin accuses positivism of describing these as cases of unconstrained discretion. In turn, Hart in his Postcript, very much indirectly adapting the interpretive stage into its theoretical framework replies: "Very often, in deciding such cases, they [judges] cite some general principle or some general aim or purpose which some considerable relevant area of the existing law can be understood as exemplifying or advancing and which points towards a determinate answer for the instant hard case". ${ }^{60}$ Although in this stage some substantive values are involved, they are not the product of individual engagement in moral reasoning by judges, in the way non-positivism constructs the practice of law, but instead the content of the social sources, since legal reasoning demands to have an internal point from where to identify principles posited or derived from past political decisions. In one way this is one important implication of positivism when it comes to a broad social philosophy: law is made by men and, as the rest of human-made tools, it accomplishes purposes ascertainable by its context and history.

\section{Postinterpretive or Reform Stage}

The postinterpretive or reforming stage, as long as it is understood as the concretization or development of the point, purposes or values of past political decisions might still keep faith with the social sources thesis as long as the argumentation employed would stick to the principles internal to that legal system, rather than resorting to external principles brought about to justify those past political decision. The

60 Ibidem, p. 274. 
Esta revista forma parte del acervo de la Biblioteca Jurídica Virtual del Instituto de Investigaciones Jurídicas de la UNAM www.juridicas.unam.mx

http://biblio.juridicas.unam.mx

\section{A SIDE EFFECT OF DWORKIN'S THEORY}

first possibility is the one defended in this paper, and the second is where Dworkin's theory makes sense a legal philosophy whereby law is inherently linked to morality.

But this needs further exploration since in this distinction between external and internal principles lies the element we want to insulate. The difference between these two kinds of principles rests on the conception of integrity we claim to be faithful to law.

\section{Integrity}

Although intuitively integrity might be seen as a formal requirement translatable to congruence or consistency, in fact, this is the most difficult concept to disentangle from non-positivist components. Integrity, for Dworkin, is a legal tradition that, unlike conventionalism and pragmatism, answers to the question of "what rights individuals have against the state" - the very question about the underlying purpose of law - in a very substantive way. To that question, integrity answers that law is not just to provide "with predictability or procedural fairness, or in some other instrumental way, but by securing a kind of equality among citizens that makes their community more genuine and improves its moral justification for exercising the political power it does."61 Integrity, in this sense, demands that rights shall be found not only when they are explicitly established in those past decision, but when "they follow from the principles of personal and political morality the explicit decisions presuppose by way of justification". ${ }^{62}$

In other words, integrity demands not only the ascertaining of purposes underlying the social sources but also that those purposes and values be justified in principles not necessarily discoverable from social sources but brought about to make of law an integral moral code. Dworkin

61 Ibidem, p. 96.

62 Idem. 
Esta revista forma parte del acervo de la Biblioteca Jurídica Virtual del Instituto de Investigaciones Jurídicas de la UNAM www.juridicas.unam.mx

http://biblio.juridicas.unam.mx

\section{DAVID GARCÍA SARUBBI}

claims this second class of principles, of justificatory nature, are those that "explicit decisions presuppose by way of justification".

But what kind principles make the case for that justification? It seems to me that this justification is the one given individually by participants from a particular moral perspective, this is to say, from principles external to the social sources; grounded in a rights-like approach to law, this is to say, it is not a justification derived and grounded within the same practice, but one constructed from principles existing outside the edifice of law where we resort to make sense of the entire phenomenon. Not principles contained or derivable from the internal point of view, due to which that practice has an existing sense, but instead comprehensible from a political and moral point of view.

Law for Dworkin answers to the question o what rights individual have against the government. To perceive those external principles doesn't require anymore the internal point of view, but a specific philosophical comprehensive and substantive position before the law. Hard cases are not solved by the narrowing or stretching of legal material by resorting to underlying principles ascertainable by the internal point of view, but by looking at law as an enterprise morally justified by reference to a meta-purpose: the granting of individuals rights. In Dworkin words: "Our discussion about law by and large assume, I suggest, that the most abstract and fundamental point of legal practice is to guide and constrain the power in the following way. Law insist that force not be used or withheld, no matter how useful that would be to these ends, except as licensed or required by individual rights and responsibilities flowing from past political decisions about when collective force is justified". 63

For Dworkin, in other words, the ideal of rule of law "is the ideal of rule by an accurate public conception of individual rights", which, again, is based in the deepest as-

63 Ibidem, p. 93. 
Esta revista forma parte del acervo de la Biblioteca Jurídica Virtual del Instituto de Investigaciones Jurídicas de la UNAM www.juridicas.unam.mx

http://biblio.juridicas.unam.mx

\section{A SIDE EFFECT OF DWORKIN'S THEORY}

sumption of law "that citizens have moral rights and duties with respect to one another, and political rights against the state as a whole". ${ }^{64}$ Past political decisions are not dispositive of cases because they are only thought to be inconclusive institutional efforts in the furnishing of rights, always to be continued and perfected under this philosophical position.

I think here it lies the element which we can insulate in Dworkin's work: judges not only use principles and purposes embedded and underlying to legal practice, ascertainable by the internal point of view and by the argumentative practice it gives place to, but they need to justify those purposes, values and principles, and make of them an integral moral code, task accomplishment of which demands from judges answering from their personal moral standing point to the question of what rights individual have against the state.

Besides this first broad characterization of integrity, which certainly demands engagement in moral reasoning, I think that Dworkin in his late work has offered an invitation to reinterpret this concept more narrowly, thought he still defends the broader one. His has hinted the idea that at the very least the value behind law might be identified with "the value of legality -or as it is sometimes more commonly called, the rule of law" which insists that the power of the state "be exercised only in accordance with standards established in the right way before that exercise". ${ }^{65}$ In other words, different conceptions of the rule of law make defend different theoretical approaches; one is the rights-approach, but there are others.

It seems to be that this second characterization of integrity as legality o re-casted in the light of the rule of law ideal, which only demands the application of standards es-

64 Dworkin, Ronald, Political Judges and the Rule of Law, Maccabaean Lecture in Jurisprudence read December 13, 1997, p. 262.

65 Dworkin, Ronald, "Hart's Postcript and the Character of Political Philosophy", Oxford Journal of Legal Studies, Vol. 24, No. 1, 2004, p. 24. 
Esta revista forma parte del acervo de la Biblioteca Jurídica Virtual del Instituto de Investigaciones Jurídicas de la UNAM www.juridicas.unam.mx

http://biblio.juridicas.unam.mx

DAVID GARCÍA SARUBBI

tablished in the right way - dependent of the ideal of the rule of law defended, for instance, the formal conception only demanding the goal of guiding human conduct respecting people's agency-, does not contain the necessary acceptance of a right-like philosophical approach from which to justify the law, but just the acceptance of the Identification Thesis, that is to say, to engage in a reasoning adopting the internal point of view from where to apprehend principles and values embedded within that practice that is attached to the ideal of the rule of law.

The important point in Dworkin's late work consists in his acknowledging that Hart's account, and positivism in general, amounts to a determinate conception of legality (and no to none as previously assumed), yet different to his rights-like approach, since "[w]e could make little sense of either legality or law if we denied this intimate connection between conceptions of legality and the identification of true claims of law". ${ }^{66}$ The idea of legality, unlike the early integrity, does not convey the overarching notion of evaluative or moral analysis from a specific philosophical position, but instead concrete developments that are "conceptual, but only in the normative, interpretive sense in which theories of justice, as well as theories of democracy, liberty and equality are conceptual". ${ }^{67}$

So at the bottom line the difference between the two conceptions of legality, non causal positivist's and Dworkin's, is a matter of the extent of their underlying ambitions. For Dworkin's conception, legality shall be supported "in a set of other, related, political values, each of these understood in turn in a way that reflects and is supported by that conception of legality" (individual moral rights). Non causal positivism, by the other hand, "emphasizes the relation between legality or efficiency", though, as Dworkin says, "[p]osistivists differ among themselves, not only because they hold somewhat different views of what political effi-

66 Ibidem, p. 25.

67 Idem.

PROBLEMA

Anuario de Filosofia y Teoría del Derecho, Núm. 8, enero-diciembre de 2014, pp. 307-352 
Esta revista forma parte del acervo de la Biblioteca Jurídica Virtual del Instituto de Investigaciones Jurídicas de la UNAM www.juridicas.unam.mx

http://biblio.juridicas.unam.mx

\section{A SIDE EFFECT OF DWORKIN'S THEORY}

ciency means, and why it is valuable, but because they also hold different views, reflected in the details of their positions, about the character and force of many other political ideals". ${ }^{68}$

We agree with the latter: there is broad disagreement among positivist and each party has its theoretical ambitions; we take as our the non-casual positivism of the formal ideal of the rule of law.

Dworkin thinks that Hart's key element in his conception of the rule of law or legality is more that of procedural fairness than efficiency (this would be his characterization of soft positivism in opposition to the casual one). ${ }^{69}$

Bringing all together in this point, yet not without problems, I think it is also possible to recast integrity in a positivist's light by relating it to a conception of the rule of law precisely defended by non-casual positivism which is the one that is more likely to profit from Dworkin's theory. The main difference between a non-casual positivist conception of integrity and a faithful dworkinian conception would be in the second operative test of justification that follows after that of fit: while dworkinians would look to justify the practice in a sound theory of individual rights against the state (by importing external principles of morality), the non-casual positivism would narrowly use the justification step only to go beyond the explicitness of past political decisions and look for underlying principles in the social sources up to the point the internal point of view would allow (internal principles) and then stretch or narrow those decision to solve hard cases according so as to what better fits the practice. From this latter position, the social sources would be composed not only of past political decisions but of values, principles and purposes as well.

68 Ibidem, p. 26.

69 Whereas for Dworkin now, the two key elements in which it is possible to divide integrity is "those of procedural fairness, which is the nerve of the dimension of fit, and substantive justice, which is the nerve of political justification". Idem. 
Esta revista forma parte del acervo de la Biblioteca Jurídica Virtual del Instituto de Investigaciones Jurídicas de la UNAM www.juridicas.unam.mx

http://biblio.juridicas.unam.mx

DAVID GARCÍA SARUBBI

\section{THE REQUIREMENT OF JUSTIFICATION}

As Gerald J. Postema notes, Dworkin sometimes is ambivalent over the specific scope of the test of fit in his general threshold to render true propositions of law. Those interpretations that pass this first muster are subject to be chosen according to two different criteria: 1) "of two surviving interpretations, one may be preferred if it provides a closer fit, requires less of the pre-interpretive data to be ruled "mistakes", etc., than its rivals do" or 2) "the competing interpretation may be preferred because, despite looser fit, it shows the practice in service to a more attractive ideal of political morality".70 I am afraid Dworkin finally solves this ambivalence, by preferring the option that presents the most compelling political moral principle.

We need to remember Dworkin argues that legal reasoning demands to make sense of past political decisions according to justificatory principles; then, the choosing of one principle might render some precedents as mistakes for they contradict the sense of the principle and the marking of "some" precedents as mistakes is necessary for the solutions of fresh cases.

But of course, there is the puzzle, not only about the amount of legal material that we are to accept to be marked as "mistake",71 but also the more defying situation mentioned by Jeremy Waldron that one of the competing interpretations fits the half of the raw data and the other fits the other half, both defending contradictory principles pushing

70 Postema, Gerald J., "Protestant Interpretation and Social Practices", Law and Philosophy, vol. 6, Issue 3, December, 1987, p. 289.

71 I don't think this question is all solved when Dworkin says that "the number of decisions I must count as mistakes is neither so great nor of such fundamental importance, viewed from the perspective of legal practice as a whole, that disregarding them leaves me no solid foundation for the more general interpretation I have just described", Law's Empire, p. 271.

PROBLEMA

Anuario de Filosofia y Teoría del Derecho, Núm. 8, enero-diciembre de 2014, pp. 307-352 
Esta revista forma parte del acervo de la Biblioteca Jurídica Virtual del Instituto de Investigaciones Jurídicas de la UNAM www.juridicas.unam.mx

http://biblio.juridicas.unam.mx

\section{A SIDE EFFECT OF DWORKIN'S THEORY}

for the defeat of the other. ${ }^{72}$ In this kind of cases Waldron thinks "Dworkin is simple wrong to think that this burden can be discharged by using one's own moral and convictions to break ties". ${ }^{73}$ For him good faith integrity requires more than this, and we could add, the conception of the rule of law would reject this as a government of men and not of law; not for Dworkin, for whom objective and justificatory principles - derived from the rights-approach- keeps the ideal of the rule of law, no matter those solutions comes from individual judges just reasoning in abstract terms.

For the purposes of this paper, I think we could say that a possible non-casual positivism's solution is to reject the protestant outfit of Dworkin's theory. Postema's thesis is that "while he regards the activity of the practice as public and collective, he Dwokin seems to regard the enterprise of understanding that activity as private and individual". In other words, whereas for Dworkin the individual moral reasoning of judges from the rights-approach in controversial cases, resorting to the best construction of external principles, is apt for the keeping of the rule of law ideal, since is the answering of the question what rights we have against the state that gives sense to the practice, the non causal positivism would demands for the solution of hard cases from public standards constructed in the same public fashion, that is to say, to resort to the advancement of the internal point of view in the construction of internal principles already existing in the practice. This is no to say it is easy to identify social consensus; specially, this is not the case in hard cases, but the methodological purpose in to advance in that goal.

In sum, the rule of law conception in a non-casual positivist fashion, conversely, would look to be more deferential to the collective elements of the practice, which is to say,

72 This is a kind of internal skepticism in the fashion of Critical Legal Studies.

73 Waldron, Jeremy, "Did Dworkin Ever Answer the Crits?", Exploring Law's Empire, Oxford, Oxford University Press, 2006, p. 181. 
Esta revista forma parte del acervo de la Biblioteca Jurídica Virtual del Instituto de Investigaciones Jurídicas de la UNAM www.juridicas.unam.mx

http://biblio.juridicas.unam.mx

\section{DAVID GARCÍA SARUBBI}

"[i]t is, rather, for one to take part with others in a collectively meaningful activity, in an activity collectively understood". ${ }^{74}$ This is a difference with the non-positivism of Dworkin, who does not emphasize this public, general, predictable feature of the rule of law.

\section{A Possible Distinction: Internal v. External Principles}

Based on all previous elements, I think we can identify two sorts of justifications: 1) internal, which defers to the collective practice and helps make principles ascertainable by the internal point of view; this is to concede law as inherently purposefully, and 2) external, which is private in character and refers to the merits of moral principles in the participant's view. I think that Dworkin refers to these external principles when claiming that participants shall try theories about the law by their own and then shall test them in face of their degree of fit, instead of ascertaining first those principles by canvassing the social sources.

This is not a matter of word-ordering: the latter methodology - defended by Dworkin- demands the importing of principles, activity which is later constrained by how they fit the practice; conversely, with the former methodology, internal principles are the creature of social sources (their ascertainable purposes). Particularly, Dworkin says that judges will rely in their own moral conception of fairness and justice and this expresses his sympathy with meta or external principles. ${ }^{75}$

An entirely internal justification, which I think would be compatible with non-casual positivism, would not accept the assertion made from the external type of justification, in the sense that to apply law it is necessary at the very be-

74 Postema, Gerald J., "Protestant Interpretation and Social Practices", Law and Philosophy, Vol. 6, Issue 3, December, 1987, pp. 288-289.

75 Dworkin, Law's Empire, p. 250. And probably this is why Dworkin says later that "integrity makes no sense except among people who want fairness and justice as well”, Ibidem, p. 263. 
Esta revista forma parte del acervo de la Biblioteca Jurídica Virtual del Instituto de Investigaciones Jurídicas de la UNAM www.juridicas.unam.mx

http://biblio.juridicas.unam.mx

\section{A SIDE EFFECT OF DWORKIN'S THEORY}

ginning to pick a set of compelling moral principles and from their content develop the constructive interpretive practice.

Non casual positivism, we insist, is only compromised with the formal ideal of the rule of law; here we can advance that contrary to Dworkin suggestion, this tradition sticks to the premise that law is a "limited domain" in the sense argued by Schauer, this is to say, "the hypothesis of law as a limited domain is at bottom a claim about the concept and scope of legal cognition"; for him, " there are in most advance legal systems a substantial quantity of otherwise valid social norms, or otherwise valid sources of decision, that law refuses to accept". ${ }^{76}$

If we are to accept the bringing about of external principles, we open doors for what Schauer characterizes as the main implication of moral-reasoning: "at least morality as we conceive of it, is the domain of practical reason that asks what one ought to dol, all reasons considered." For him, law exists against a background of broad moral disagreement, whereby is exerts the function of settlement, but "law can fulfill this role only if its domain -the reasons law consults to determine what ought to be done- is less than that of all practical reasons or even of all moral reasons". If law is to settle moral disagreement, by guiding conduct, in the fashion of the rule of law ideal, it cannot open up for the bringing of external principles, because that would mean "to embroil the citizens in never-ending and enormously morally costly controversy over what the law required". ${ }^{77}$

Here fits the compatibility of positivism with the formal conception of the rule of law, as a government of law and not of people, as a device for the guiding of human conduct: "in the decidedly real world in which the commands of morality are both uncertain and contested, law provides

76 Schauer, Frederick, "The Limited Domain of Law", Virginia Law Review, vol. 90, No. 7, 2004, p. 1917.

77 Idem. 
Esta revista forma parte del acervo de la Biblioteca Jurídica Virtual del Instituto de Investigaciones Jurídicas de la UNAM www.juridicas.unam.mx

http://biblio.juridicas.unam.mx

\section{DAVID GARCÍA SARUBBI}

much-needed practical guidance by greatly reducing the amount of knowledge required to make practical decisions". "Law thus carries out is guidance function by limiting its domain of reasons, and in doing so furthers morality by enabling huge moral costs to be avoided". "Thus, what we have called law's settlement function is ultimately a shorthand for law's role in providing practical guidance and thus reducing the moral costs that would exists in its absence". ${ }^{78}$

In this respect, Schauer concludes "[j]ust as an individual rule achives predictability, stability, and constraint on decision-maker discretion by cutting of access to even some relevant reasons and considerations, so does a legal system achieve the same goals, and achieve the virtues of moral settlement in the face of moral disagreement, by similarly cutting off access to some relevant reasons and considerations". ${ }^{79}$

In other words, the internal justification approach I want to isolate for the benefit of positivism would separate partly from Dworkin when making this concept of law as a limited domain blurring, and, then, when saying that "[i]f a supportive conception of law offers to find in the general structure of a particular community's legal practice a political justification of coercion, then it should not be supportive, but in some way skeptical, about legal systems that lack features essential to that justification". ${ }^{80}$ I claim partial separation, because, non-casual positivism still stick to the idea of the rule of law, which could amount to the denying of some very wicked legal systems as law (those lacking of the needed features for the guiding of human conduct), but as Hart would argue referring to its equivalent, the "inner morality of law", accepting this limitation still accepts that law is "unfortunately compatible with very great iniquity",

78 Idem.

79 Schauer, Frederick and Alexander, Larry, "Law's Limited Domain Confronts Morality's Universal Empire”, William \& Mary Law Review, April 2007.

80 Dworkin, Ronald, Law's Empire, Cambridge, Massachussets, Harvard University Press, 1986, p. 103. 
Esta revista forma parte del acervo de la Biblioteca Jurídica Virtual del Instituto de Investigaciones Jurídicas de la UNAM www.juridicas.unam.mx

http://biblio.juridicas.unam.mx

\section{A SIDE EFFECT OF DWORKIN'S THEORY}

exactly because of its general barrier to external and imported moral principles. ${ }^{81}$

The difference is that this non-casual positivism would try to develop the Identification Thesis, that is to say, would engage in the construction of internal principles that give independence to the legal order in the way of public standards, rather than searching for the justification about the individual moral rights every legal system conforms against the state, the importation of external principles whereby individual rights might appear to be justified. ${ }^{82}$

For non causal positivism, the question of the rule of law is not ask from a independent political ground what rights individuals have against the state, but if the public standards embedded in the legal order is applied in a compatible way to the ideal of the rule of law, according to which law as a social tool of regulation of human conduct where human agents are rational individuals with autonomy capable of rendering obedience to law, when it comes to law to settle disagreement .

The justification accordingly with internal principles would comply the function of rationalize law by articulating the content of social sources within the legal framework. The internal point of view would demand from participants not the engaging in moral reasoning but the keeping of a certain degree of rationality; in this sense, detached from external moral views is capable, nevertheless, to perceive the reasons to which norms and laws might be traceable to, making understandable the idea of arbitrariness within the law. As Timothy A. O. Endicott claims: "Government is arbitrary if its actions depart from the reasons of the law". ${ }^{83}$

81 Hart, H. L. A., The Concept of Law, 3rd. ed., Oxford, Oxford University Press, 2012, p. 207.

82 This last philosophical approach is a compelling one but one hardly universalized as a general theory of law.

83 Endicott, Timothy A. O., "The impossibility of the Rule of Law", Oxford University Press, 1999, p. 3. He gives three senses of the notion of arbitrary, all of which have to do with the absence of rules (the uncon- 
Esta revista forma parte del acervo de la Biblioteca Jurídica Virtual del Instituto de Investigaciones Jurídicas de la UNAM www.juridicas.unam.mx

http://biblio.juridicas.unam.mx

\section{DAVID GARCÍA SARUBBI}

Of course, one might reply that this distinction between internal and external principles is artificial in the worst case and only a difference of degree rather of kind in the best. However, I think that this distinction could help us to discriminate finely among legal analysis. ${ }^{84}$

From another angle, this idea of justification based on internal principles, which sticks with the ideal of law a limited domain would allow positivism not to resign to its important effort to inhibit judges to engage on their own in moral reasoning in a way that is at least invited by Dworkin. Positivist need to acknowledge, as J.M. Balkin suggests, that "[i]f we are ruled by law, we are ruled by texts, and if we are ruled by texts, we are ruled by readings of text". ${ }^{85}$ However, the achievement of the ideal of the rule of law cannot be thrown out in the reading of those norms, this is to say, judges shall not have unfettered discretion in interpreting legal texts, though they think they are applying the best justification of public coercion.

\section{CONCLUSION}

Core Dworkinian concepts do not yield a necessary relationship between law and morality. When put together in the way Dworkin structured his work, those concepts amount to a complete and convincing theory challenging positivism's claim pertaining the social sources thesis. However, concepts such as integrity, constructive interpre-

strained effective will of rulers, inconsistently decisions, and unpredictability).

84 One example of this is Waldron's concept of legal arquetypes: "one provision in the cluster which by virtue of its force, clarity, and vividness expresses the spirit that animates the whole area of law". This is a technique that includes in legal argumentation principles that are internal to the legal practice in a clear way, by identifying norms that have become "a sort of emblem, token, or icon of the whole". "Torture and Positive Law", Columbia Law Review, Vol. 105, No. 2005.

85 Balkin, J. M. cited in Lynne Henderson, "Authoritarianism and the Rule of Law”, Indiana Law Journal, Vol. 66, No. 2, 1991, pp. 419-420. 
Esta revista forma parte del acervo de la Biblioteca Jurídica Virtual del Instituto de Investigaciones Jurídicas de la UNAM www.juridicas.unam.mx

http://biblio.juridicas.unam.mx

\section{A SIDE EFFECT OF DWORKIN'S THEORY}

tation, internal point of view and personification, are neither for their own sake incompatible nor foreign to positivism. These concepts only render a necessary relationship between law and morality if one uses them under a rights-like approach (from the importing of external principles), this is, when those analytical tools are used to answer a very conditioning question: what moral rights do citizens have against their government? Also they render this link necessary if we accept, as a threshold of true propositions of law, the bringing about of external moral principles that might justify the legal practice from outside, rather than limiting the justifying function of argumentation to internal principles, deferential to the social practice.

Bringing those dworkinian concepts in the way re-casted in this paper would permit non-casual positivism be faithful to its commitment to explain law as technique of government of law and not of men. In hard cases the argumentative practice of law is able to stretch or narrow the preinterpretive legal material accordingly to principles internal to the legal system, to render judges's powers, in Hart's words, "interstitial as well as subject to many substantive constraints" 86 in ways not arbitrarily.

Under this conception, the discretion to which judges are empowered is not something bad to lament about. In Hart's words: "we should not cherish, even as an ideal, the conception of a rule so detailed that the question whether it applied or not to a particular case was always settled in advance, and never involved, at the point of actual application, a fresh choice between open alternatives". We could say that discretion under a second best theory approach is desirable because of our relative ignorance of fact and our relative indeterminacy of aim. ${ }^{87}$ This re-reading of non causal positivism under Dworkinian concepts would permit to the legal systems openly comply with a necessary promise involved in any system of government: the leaving open

86 Hart, H. L. A., The Concept of Law, 3rd. ed., p. 273.

87 Ibidem, p. 128. 
Esta revista forma parte del acervo de la Biblioteca Jurídica Virtual del Instituto de Investigaciones Jurídicas de la UNAM www.juridicas.unam.mx

http://biblio.juridicas.unam.mx

\section{DAVID GARCÍA SARUBBI}

"for later settlement by an informed, official choice, issues, which can only be properly appreciated and settled when they arise in a concrete case", without in turn resorting to the individual morality of judges. ${ }^{88}$

We need to remember, as Waldron claims, that we value the rule of law not only for the mechanical application of rules, but rather for the channeling, supporting and fostering of intelligence and argumentation. Law, as we know, contains not only rules but also standards and factors, and, all together, this toolbox of norms produce a legal argumentative practice which nowadays we take for granted without thinking that those processes necessarily imply the engagement in moral reasoning in vacuum. ${ }^{89}$

I know that this presentation of Dworkin's concepts leaves more questions than answers. For example, how are we to distinguish between internal and external principles to know which can justify the practice? What is exactly the formal ideal of the rule of law attached to non casual positivism? What operative model would be the alternative to present law as an argumentative practice? I think that these and other more, are the crucial question for non-casual positivism to answer and my purpose is just to signal this path of questions once it is realized that this legal tradition might still compete with non-positivist tradition as that of Dworkin.

VIII. BIBLIOGRAPHY

BIX, Brian, and Coleman, Jules, "Legal Positivism, and Legal Authority", Quinnipiac Law Review, Vol. 16, No. 241, 1996.

88 Ibidem, p. 130.

89 Waldron, Jeremy, The Rule of Law and the Importance of Procedure, New York University Public Law and Legal Theory Working Papers, Paper 234, 2010. 
Esta revista forma parte del acervo de la Biblioteca Jurídica Virtual del Instituto de Investigaciones Jurídicas de la UNAM www.juridicas.unam.mx

http://biblio.juridicas.unam.mx

\section{A SIDE EFFECT OF DWORKIN'S THEORY}

BoвBIo, Norberto, El problema del positivismo jurídico, trans. Ernesto Garzón Valdés, México, Fontamara, 1991.

CAMPBELl, Tom, "Rewriting Hart's Postcript: Thoughts on the Development of Legal Positivism", Problema. Anuario de Filosofía y Teoría del Derecho, num. 5, 2011.

Coleman, Jules, The Practice of Principle: In Defense of a Pragmatist Approach to Legal Theory, Oxford, Oxford University Press, 2001.

Dworkin, Ronald, Law's Empire, Cambridge, Massachussets, Harvard University Press, 1986.

DWORKIN, Ronald, "Hart's Postcript and the Character of Political Philosophy", Oxford Journal Legal Studies, Vol. 24, No. 1, 2004.

Dworkin, Ronald, Political Judges and the Rule of Law, Maccabaean Lecture in Jurisprudence read December 13, 1977.

ENDICOTT, Timothy A. O., "The impossibility of the Rule of Law", Oxford University Press, 1999.

FINNIS, John, "Law and What I Truly Should Decide", The American Journal of Jurisprudence, vol. 48, 2003.

FULLER, Lon, "The Morality of Law", Revised Edition, Yale University Press, New Haven, 1969.

HART, H. L. A., The Concept of Law, 2nd. ed., Oxford and New York, Oxford University Press, 1994.

HENDERSON, Lynne, "Authoritarianism and the Rule of Law", Indiana Law Journal, Vol. 66, No. 2, 1991.

KELSEn, Hans, Pure Theory of Law, translated by Max Knight, Berkeley and Los Angeles, University of California Press, 1967.

Moore, Michael S., "Law and Morality: Four Reflections on Law and Morality", William \& Mary Law Review, Vol. 48, 2007. 
Esta revista forma parte del acervo de la Biblioteca Jurídica Virtual del Instituto de Investigaciones Jurídicas de la UNAM www.juridicas.unam.mx

http://biblio.juridicas.unam.mx

\section{DAVID GARCÍA SARUBBI}

PostemA, Gerald J., "Protestant Interpretation and Social Practices", Law and Philosophy, Vol. 6, Issue 3, December 1987.

Problema. Anuario de Filosofía y Teoría del Derecho, UNAM, Instituto de Investigaciones Jurídicas, 2011.

RAZ, Joseph, "The Authority of Law", New York, Oxford University Press, 2009.

SCHAUER, Frederick, "The Limited Domain of Law", Virginia Law Review, vol. 90, 2004.

SCHAUER, Frederick and ALEXANDER, Larry, "Law's Limited Domain Confronts Morality's Universal Empire", William \& Mary Law Review, April 2007.

TAMANAHA, Brian, "A Concise Guide to the Rule of Law", St. John's University, paper 07-0082, September 2007.

VÁZQUEZ, Rodolfo, Entre la libertad y la igualdad. Introducción a la filosofía del derecho, Madrid, Trotta, 2006.

WALDRON, Jeremy, "The Concept and the Rule of Law", Georgia Law Review, Vol. 43, No. 1, Fall 2008.

WALDRON, Jeremy, "Retroactive Law: How Dodgy was Duynhoven?", Otago Law Review, Vol. 10, No. 4, 2004.

WALDRON, Jeremy, "The Rule of Law as a Theater of Debate", Dworkin and his Critics: with Replies by Dworkin, Edited by Justine Burley, Oxford, Blackwell Publishing, 2004.

WALDRON, Jeremy, "Did Dworkin Ever Answer the Crits?", Exploring Law's Empire, Oxford, Oxford University Press, 2006.

WALDRON, Jeremy, "Torture and Positive Law", Columbia Law Review, Vol. 105, No. 2005.

WALDRON, Jeremy, The Rule of Law and the Importance of Procedure (2010), New York University Public Law and Legal Theory Working Papers, Paper 234. 